\title{
Conducting Home Interviews - Possible to Learn and Deepen Understanding on Some Practical and Ethical Issues
}

\author{
Heinonen Kristiina PhD, MNSc, Teacher, RN, PHN ${ }^{1,2^{*}}$ \\ ${ }^{1}$ Post-doctoral research affiliate at Nord University, Bodø, \\ Norway. \\ ${ }^{2}$ Department of Nursing Science, University of Eastern Finland, \\ Finland. \\ "Correspondence: \\ Heinonen Kristiina, Post-doctoral research affiliate at Nord \\ University, Bodø, Norway and Department of Nursing Science, \\ University of Eastern Finland, Finland. \\ Received: 05 February 2018; Accepted: 26 February 2018
}

Citation: Heinonen K. Conducting Home Interviews - Possible to Learn and Deepen Understanding on Some Practical and Ethical Issues. Nur Primary Care. 2018; 2(1): 1-8.

\section{ABSTRACT}

Background: The systematic literature and knowledge review reveals that it is important to discuss home interviews practical and ethical questions. This research uses a hermeneutic phenomenological research approach.

Aim: To describe some practical and ethical issues in conducting home interviews as exemplified by multiple-birth families.

Participants and Research Context: The data consists of open-form interviews with multiple-birth family parents (12 mothers and 7 fathers), the documents they sent in writing thereafter, and the researcher's notes. The authentic context yielded rich data on parents' experiences.

Ethics approval for this research was obtained from the Ethics Committee of the University Hospital and the relevant health care organizations.

Results: A face-to-face in-person interview in the participant's own area gives a good possibility to have rich data and to see non-verbal communication. The lifeworld of the parent of multiples can be described as " $a$ state of constant vigilance", "ensuring that they can continue to cope", and "opportunities to share with other people".

Discussion: Ethical questions are important in every situation throughout the whole research process. These questions involve visiting participants' homes, having oral and written consent, respecting interaction with them and their children's safety, and knowing and respecting guidelines. Gathering data at home needs strong ethics, high sensitivity, flexibility, and enough time. Careful planning is needed also for safety, especially that of children.

Conclusion: Home interviews are specific situations that require effective communication between the researcher and participants. It means that the researcher needs to prepare for the situation carefully, concentrate, and harness all of their senses. Supervisor support providing discussion and the opportunity to reflect on the researcher's experience is important. Simulation pedagogy could support researchers'skills and lead to mutual learning.

\section{Keywords}

Phenomenology, Hermeneutics, Ethics, Interview, Home, Simulation pedagogy.

\section{Introduction}

In phenomenology and hermeneutics it is important to have rich data. Such data can enhance the trustworthiness and ethics of the research. Nursing is based on holistic understanding, humanistic values, and the rights of human beings, which should be respected in data gathering as well. The phenomenological interview is used as a means of exploring and gathering experiential material and the hermeneutic interview to explore interpretative meanings of material obtained from the phenomenological interview or other data sources [1]. Gathering data in the participants' homes 
facilitates the obtaining of in-depth descriptions of participants' experiences.

Research is facilitated when the participants feel at home, both literally and figuratively. For both interviewer and interviewee influence the interview, stage can include understanding, exploration, co-operation, and participation [2]. In any research project researchers are involved in different kinds of ethical questions $[3,4,5]$. Sorsa $M$, et al. [6] state that adequately skilled and experienced researchers are required to practise semistructured qualitative research interviews. Novice interviewers should preferably practise the method repeatedly, under the supervision of an experienced qualitative researcher [7].

A sensitive researcher can pay attention to participants' hints and interact flexibly during the unstructured research interview $[1,6,8]$. Sorsa M, et al. [6] states that health care professionals are practically involved in ethical questions in their work as well as during research interviews. Simulation pedagogy makes it possible to practise different kinds of situations in an almost real context. This and other pedagogical approaches might allow students to practise and cope better with varied situations and real clinical environments [9].

A multiple-birth family is one that is expecting or has sameage children, such as twins. Multiple-birth family research has focused on mothering [10-12] and parenthood [13-16], motherchild relations [17] and also on unborn twins [18], early parental interaction [19], twins' sleeping [20], and parents' experiences to inform service provision [21]. Previous research emphasizes the need for better understanding of such families by professionals [11,13,21-23]. These families are entitled to receive appropriate information related to improving the well-being and health of the family and parenting children with a focus on supporting individual growth and development [24,25].

There are only a few previous studies where the data has been gathered by home interviews [12,15-18,20,21], but studies have also been carried out in hospitals, workplaces, libraries, and by telephone $[13,26]$, triplets [16] have been interviewed. Goshen-Gottstein ER [12] interviews included also families with quadruplets. Some of the interviews included only mothers $[18,21]$ and some both parents $[15,19,22]$. What is missing are the researchers' experiences of ethics and practical issues when conducting interviews at homes.

\section{Aim}

This article describes the practical and ethical issues of interviewing in the home using multiple-birth families as an example.

\section{Methodology}

This research uses van Manen's hermeneutic phenomenological research approach. One method of phenomenological research is to "borrow" other people's experiences. The phenomenological interview's primary aim is to gather pre-reflective experiential accounts. The lifeworld, the world of everyday lived experience, is both the source and the object of phenomenological research. It aims to remain truthful to the original hermeneutic phenomenological methods. Methodologically, phenomenology is rooted in various onto-epistemological and ethics-oriented philosophies that aim at meaningful understanding and insight into the lived meanings of human phenomena [1,27]. van Manen M [1] finds the uniqueness of phenomenology lies in searching for and depicting living meaning. Phenomenology tries to understand something while it is happening in the moment, which makes it different from other forms of qualitative inquiry. In this unending phenomenological quest, researchers open up a familiar question, which is how to understand the meaning or meaningfulness of a human phenomenon $[1,27,28]$.

\section{Participants}

The participants were parents of twins under 5 years: the mothers were aged 26 to 40 ; the fathers 26 to 45 . They were married with academic or practical background, and they lived in cities or in the countryside. All of the twins were non-identical; although in one case not verified. Five of these families also had other siblings.

\section{Data}

This research uses a hermeneutic phenomenological research approach and the data consists of parents' open-form interviews, the documents they sent in writing thereafter, and researcher's notes. The phenomena of the lifeworld of multiple-birth families and their needs for support as described by parents are: "A state of constant vigilance", "Ensuring that they can continue to cope" and "Opportunities to share" [29-31].

\section{Findings}

This section presents some practical and ethical issues that became apparent during the research and interviews (Figure 1).

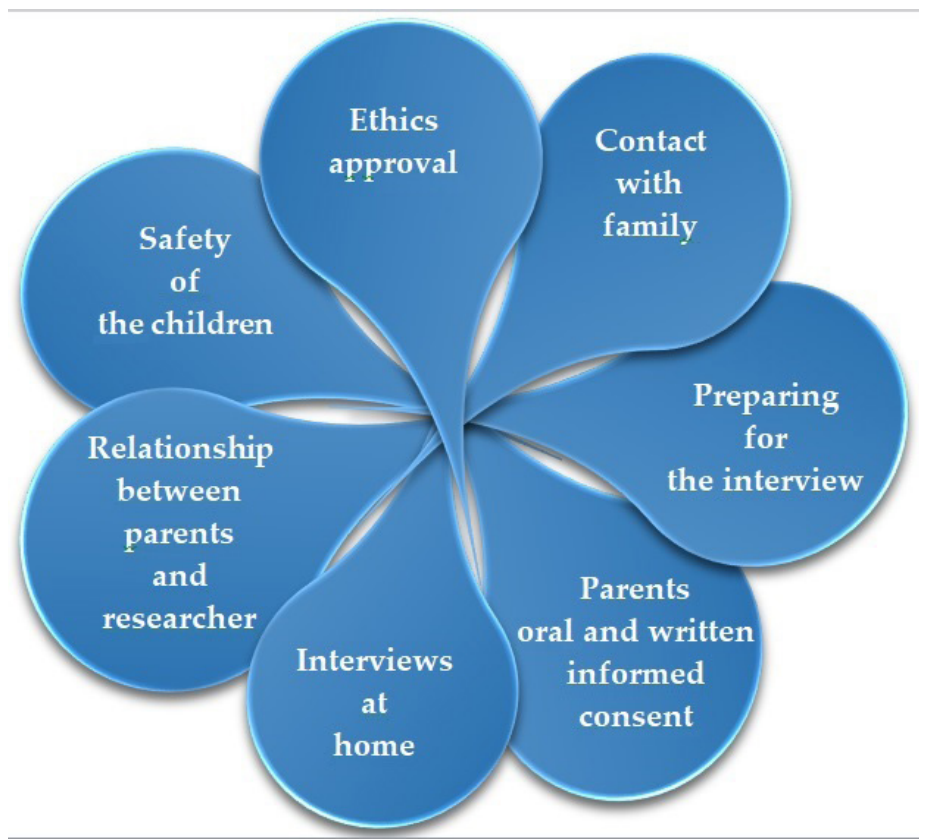

Figure 1: Some ethical points doing home interviews. 


\begin{tabular}{|c|c|c|c|c|c|}
\hline Research & Purpose of research & Participants & Method & Analysis & Some results \\
\hline $\begin{array}{l}\text { Goshen-Gottstein, E.R. } \\
\text { (1980) } \\
\text { The mothering of twins, } \\
\text { triplets, and quadruplets. } \\
\text { Psychiatry, 43, 189- } 204 . \\
\text { Country: Israel }\end{array}$ & $\begin{array}{l}\text { To obtain mothers' reported } \\
\text { reactions when faced with } \\
\text { the tidings of the arrival } \\
\text { of multiple infants and } \\
\text { study mothers' means of } \\
\text { coping with and their ways } \\
\text { of relating to these twins, } \\
\text { triplets, and quadruplets. } \\
\text { What are the issues that face } \\
\text { a mother of twins or super } \\
\text { twins and how do these } \\
\text { issues express themselves? }\end{array}$ & $\begin{array}{l}\text { Families: } \\
\mathrm{n}=4 \text { families of } \\
\text { twins, } \\
\mathrm{n}=6 \text { families of } \\
\text { triplets, and } \\
\mathrm{n}=4 \text { families of } \\
\text { quadruplets }\end{array}$ & $\begin{array}{l}\text { Observational method was } \\
\text { used. } \\
\text { Families were visited at } \\
\text { home monthly for several } \\
\text { hours and from the infants' } \\
\text { fifth month until their } \\
\text { second year and thereafter } \\
\text { at bimonthly intervals. Of } \\
\text { these } 14 \text { families, } 12 \text { were } \\
\text { observed until the children } \\
\text { were four to six years old. }\end{array}$ & $\begin{array}{l}\text { Transcripts were made of } \\
\text { the observations and later } \\
\text { categorized. Special attention } \\
\text { was paid to the amount and kinds } \\
\text { of physical, emotional, social, } \\
\text { and verbal contact the mother } \\
\text { gave to each child, her degree } \\
\text { of responsiveness to his or her } \\
\text { needs, and what she said to or } \\
\text { about the child; how the mother } \\
\text { actually behaved; the mother's } \\
\text { quantitative and qualitative } \\
\text { behaviour. }\end{array}$ & $\begin{array}{l}\text { Mothers found it difficult to meet } \\
\text { children's needs simultaneously; } \\
\text { they were more ambivalent and } \\
\text { negative than single mothers } \\
\text { and singletons. They were } \\
\text { psychologically unprepared as they } \\
\text { themselves had been singletons. } \\
\text { Mothers who coped better had } \\
\text { related professional training and } \\
\text { they treated their children as } \\
\text { individuals. }\end{array}$ \\
\hline $\begin{array}{l}\text { Holditch-Davis, D., Roberts, } \\
\text { D. \& Sandelowski, M. } \\
\text { (1999). Early parental } \\
\text { interactions with and } \\
\text { perceptions of multiple birth } \\
\text { infants. } \\
\text { Journal of Advanced } \\
\text { Nursing, 30(1), 200-210. } \\
\text { Country: USA }\end{array}$ & $\begin{array}{l}\text { To examine how mothers } \\
\text { and fathers interact with } \\
\text { multiple-birth infants and } \\
\text { perceive parenting them } \\
\text { in the early weeks after } \\
\text { delivery and to compare } \\
\text { these interactions and } \\
\text { perceptions with those of } \\
\text { parents of singletons. }\end{array}$ & $\begin{array}{l}\text { Mothers and } \\
\text { fathers } \\
\mathrm{n}=7 \text { of seven } \\
\text { (twins) } \\
\text { and } \mathrm{n}=1 \\
\text { (triplets) were } \\
\text { compared with } \\
\text { those of parents } \\
\text { of } 49 \text { singleton } \\
\text { infants. }\end{array}$ & $\begin{array}{l}\text { Couples were typically } \\
\text { interviewed together three } \\
\text { times during pregnancy and } \\
\text { at } 1 \text { week and } 3 \text { months } \\
\text { post-partum. } \\
\text { Fortnightly observations } \\
\text { of mother-father-infant } \\
\text { interactions were conducted } \\
\text { after the first postnatal } \\
\text { interview. }\end{array}$ & $\begin{array}{l}\text { For all statistical analyses } \\
\text { comparing the groups, only one } \\
\text { infant from each multiple group } \\
\text { was used. Home interviews, } 4 \text { to } \\
5 \text { times. Interviews began with } \\
\text { an opening question and were } \\
\text { unstructured. } \\
\text { Interviews were audio-taped } \\
\text { and then transcribed verbatim. } \\
\text { Qualitative content analysis was } \\
\text { used. }\end{array}$ & $\begin{array}{l}\text { Three major themes were apparent } \\
\text { in the interviews: the positive and } \\
\text { negative specialness of multiple } \\
\text { births, difficulties involved in } \\
\text { managing more than one infant, and } \\
\text { attachment issues. Multiple-birth } \\
\text { infants were left alone more and } \\
\text { looked at, talked to, and held less } \\
\text { often than singletons. }\end{array}$ \\
\hline $\begin{array}{l}\text { Heinonen, K., Moilanen, } \\
\text { I. \& Pietilä, A.-M. (2007). } \\
\text { Experiences of support by } \\
\text { parents of multiple birth } \\
\text { children-an interview } \\
\text { study. } \\
\text { Nursing Science, 19(4), } \\
\text { 223-35. } \\
\text { Country: Finland }\end{array}$ & $\begin{array}{l}\text { To show how multiple- } \\
\text { birth families experience } \\
\text { their parenthood and their } \\
\text { resources and the factors } \\
\text { that improve their coping in } \\
\text { daily life. }\end{array}$ & $\begin{array}{l}\mathrm{n}=14 \text { parents } \\
\text { with under-4- } \\
\text { year-old twins }\end{array}$ & Home interviews & $\begin{array}{l}\text { The interviews were taped and } \\
\text { transcribed. } \\
\text { Qualitative content analysis } \\
\text { method was used. }\end{array}$ & $\begin{array}{l}\text { Everyday life was productive and } \\
\text { full of activity. The questions the } \\
\text { parents had to face were objectivity, } \\
\text { sense of justness, as well as feelings } \\
\text { of inadequacy, being thankful, and } \\
\text { being in flux. The lack of both sleep } \\
\text { and a daily rhythm were considered } \\
\text { demanding and harmful. Parents } \\
\text { wanted to have more support and } \\
\text { information from social and health } \\
\text { care professionals. }\end{array}$ \\
\hline $\begin{array}{l}\text { Ball, H.L. (2007). } \\
\text { Together or apart? A } \\
\text { behavioral and physiological } \\
\text { investigation of sleeping } \\
\text { arrangements for twin } \\
\text { babies. } \\
\text { Midwifery, 23(4); 404-12 } \\
\text { Country: UK }\end{array}$ & $\begin{array}{l}\text { To explore the behaviour and } \\
\text { physiology of twin babies } \\
\text { sleeping separately and } \\
\text { together. }\end{array}$ & $\begin{array}{l}\text { In the first part of } \\
\text { study } n=10 \text { twin } \\
\text { baby pairs aged } \\
\text { between } 1 \text { to } 3 \\
\text { months (home) } \\
\text { In the second part } \\
\text { of study } n=14 \\
\text { twin baby pairs } \\
\text { under } 3 \text { months } \\
\text { (monitored in a } \\
\text { sleep lab) }\end{array}$ & $\begin{array}{l}\text { Videotaped sleeping } \\
\text { together at home in head- } \\
\text { to-head and side-by-side } \\
\text { configurations }\end{array}$ & $\begin{array}{l}\text { Video material at home. Guide } \\
\text { for parents on how to care for } \\
\text { their children as normal and also } \\
\text { to show them how to use remote } \\
\text { control to halt the recording at } \\
\text { any point they felt was necessary. }\end{array}$ & $\begin{array}{l}\text { In the first part of the research: } \\
\text { sleep variables were unaffected by } \\
\text { co-bedding configuration. Babies } \\
\text { positioned side by side were } \\
\text { observed to occasionally impinge } \\
\text { on, but not obstruct, one another's } \\
\text { airways, with an arm across the } \\
\text { other's face. In a second part, no } \\
\text { difference was found in twins' } \\
\text { duration of sleep, frequency of } \\
\text { waking, core temperature, or head } \\
\text { covering in the two conditions; co- } \\
\text { bedded twins showed synchronous } \\
\text { sleep states. }\end{array}$ \\
\hline $\begin{array}{l}\text { Bolch, C.E., Umstad, M.P., } \\
\text { \& Fisher, J.R.W. (2012). } \\
\text { Multiple birth families with } \\
\text { children with special needs: } \\
\text { a qualitative investigation of } \\
\text { mother's experiences. } \\
\text { Twin Research and Human } \\
\text { Genetics, 15(4), 503-515. } \\
\text { Country: Australia }\end{array}$ & $\begin{array}{l}\text { To describe and interpret the } \\
\text { experiences of mothers of } \\
\text { premature born multiple- } \\
\text { birth children with diverse } \\
\text { special needs. }\end{array}$ & $\begin{array}{l}\mathrm{N}=10 \text { mothers } \\
\text { of multiples with } \\
\text { special needs }\end{array}$ & $\begin{array}{l}\text { Interviews (in the mother's } \\
\text { home, at the hospital, or at } \\
\text { another location suggested } \\
\text { by the mother or telephone } \\
\text { interview). Three mothers } \\
\text { were interviewed in their } \\
\text { own home. } \\
\text { Questions were non- } \\
\text { directive and open-ended }\end{array}$ & $\begin{array}{l}\text { The qualitative technique of } \\
\text { thematic analysis. }\end{array}$ & $\begin{array}{l}\text { Having more than one baby } \\
\text { created practical and psychological } \\
\text { problems during the neonatal } \\
\text { period, especially when infants } \\
\text { were separated due to differences } \\
\text { in medical status. The presence } \\
\text { of guilty feelings, particularly } \\
\text { regarding inequality of care and } \\
\text { attention they were able to provide } \\
\text { to each child. }\end{array}$ \\
\hline $\begin{array}{l}\text { Harvey, M.E., Athi, } \\
\text { R., Denny, E. (2014). } \\
\text { Exploratory study on } \\
\text { meeting the health and social } \\
\text { care needs of mothers with } \\
\text { twins } \\
\text { Community Practitioner, } \\
87(2), 28-31 . \\
\text { Country: UK }\end{array}$ & $\begin{array}{l}\text { To gain insight into parents' } \\
\text { experiences and to inform } \\
\text { service provision. }\end{array}$ & $\begin{array}{l}\mathrm{n}=7 \text { mothers of } \\
\text { twins }\end{array}$ & $\begin{array}{l}\text { Audio-taped semi- } \\
\text { structured interviews were } \\
\text { conducted in the mothers' } \\
\text { home. }\end{array}$ & $\begin{array}{l}\text { The interviews were transcribed } \\
\text { verbatim and analysed using } \\
\text { thematic analysis, qualitative } \\
\text { method. }\end{array}$ & $\begin{array}{l}\text { Identified themes: Assumptions vs } \\
\text { reality, worries and concerns, impact } \\
\text { on self and sources of support. } \\
\text { Mothers worried about preterm birth } \\
\text { and the effect of a multiple birth on } \\
\text { their family life including health and } \\
\text { wellbeing; other issues were coping } \\
\text { and the gap between support needed } \\
\text { and received. The community-based } \\
\text { care received. }\end{array}$ \\
\hline
\end{tabular}

Table 1: Some examples of research done in multiple-birth family homes. 
Ethics approval

Ethics approval for this research was obtained from the Ethics Committee of the University Hospital and the relevant health care organizations. The application included an explanation of how to support and guide such families if researcher noticed the need for support during interviews. Receiving a positive statement set researchers mind at ease and allowed to proceed with no qualms. Special attention needed to be paid to vulnerable groups such as pregnant or breastfeeding women [3].

\section{Contact with family}

Professionals working at child and maternity welfare clinics contacted the participants in their respective areas. The heads of these clinics were contacted and professionals attended a local area information meeting. The nurses sought participants' permission to give their contact information to researcher. Only multiplebirth parents were asked to participate because the focus was on such parenthood. Getting their express consent at the outset was done respecting participants' privacy and their rights of self-determination. Then researcher telephoned the participants, informed them about the study and its practical arrangements including a discussion about organizing care for the twins and siblings and let participants mull over their decision. Most of them consented to participate during the first telephone call. Letters with information about the research were posted to the participants. Later, researcher contacted them to learn their decision without any coercion. The requested duration for a meeting was two hours.

Nineteen parents underwent interviews; only one opted for a university venue. Researcher tried to avoid inconvenience to the participants who decided, on the times. Their decision was based on factors such as the daily rhythm of their children, the parents' work time and babysitter arrangements. The interviews took up to two hours, were tape-recorded after obtaining participants' permission, and transcribed verbatim. The Finnish Advisory Board on Research Integrity [32] guidelines include respecting participants' self-determination, autonomy and privacy, protecting data, and avoiding any harm.

\section{Preparing for and reflecting on the interview}

An interview involves delving into and dwelling on-albeit temporarily - the unique universe of the host family, respecting the time given and their life situation just as it is. Preparing for an open-ended interview necessitates preparing for the situation carefully, concentrating, and harnessing all of one's senses. On the way home, researcher had a good opportunity to reflect on the whole situation and experiences. The interviews (maximum two a day) were so unique that they were easily recalled. Researchers diary was an important research tool both for reflection and development as a researcher.

\section{Interviews at home}

Although few would interpret a home interview as an invasion of privacy, researchers have to bear in mind that her entry is in effect an intrusion, an invasion of private space. Researcher tries to minimize this disturbance. Home interview dynamics require that both parents be mutually accommodating. Reid J, et al. [34] researcher also felt that she was warmly accepted and treated valued and welcomed "guest".

The semi-structured interview schedule of [3] has three main parts: introductory remarks, body, and closing remarks, which also applies other interview types. At first, we discussed their daily life; for example, participants talk about the neighbourhood. This brief discussion came to a close with researchers checking that researcher had permission to record. Only one family refused to be taped. However, all families allowed taking notes. Participants gave information on the research; their oral and written informed consent was obtained. Discussion follows asking for family background information from participants, twins and family members $[3,33]$. Conversations require the right kind of place, atmosphere, tone, and time [1].

In the second part, the participants were free to withhold some information and not to discuss those issues. They could withdraw from the research at any stage, without specifying reasons. All the interviews began with requesting that the participants tell something about support for multiple-birth families; researcher later encouraged participants to describe and exemplify. At the end of the interview, researcher inquired as to whether they had anything to add $[33,34]$. Some participant had comments; a few had some clarifications to offer. The body contains the questions reflecting the central aims of research project; it may also include the most sensitive and difficult questions [3].

In the final stage, researcher asked them about their experiences, urging them to freely express their feelings about the interview itself. A few participants confided that the taping was initially disturbing, but they forgot about it as the interview proceeded. They found it important to discuss with researcher, to have someone to really listen to their experiences. Researcher advised them to send their written documents within a fortnight. This channel also gave them an opportunity to open up. Next, researcher checked whether they had any residual negative feelings. They had researchers contact information for later use. The closing stage follows the interview very naturally. Closing remarks should reflect a concerted effort to provide the interviewee and interviewer with some closure [3].

The participants have a possibility to send their written documents afterwards. There is an ethical aspect to doing member checks; they should be part of the research plan. Researcher didn't find it necessary to show the data to the participants and to take more of their time. Member checks could deepen understanding, but later researcher received a lot of feedback from parents, which implied that the lifeworld of such families had really discovered [23,32].

\section{The parents-researcher relationship}

Researchers need to strike a balance between obtaining adequate data and interrupting the normal flow of family life. Being wholly present is an acknowledgement of the participant's goodwill in inviting researcher into their home. Interviews were conducted in open and friendly atmosphere which could be seen parents relax, 
open minded and fee willing to tell different kind of feelings and subjects to researcher and having feeling that there is a person who is really interested in them and their life. Researcher give place to parents, have own time to tell and possibility to share through the open-interview. Post-interview communication as a channel can facilitate the discussion of not-so-pleasant aspects, extend topics already touched upon, exemplify points, and mutually clarify issues, including data interpretation. Interviewees can be in touch with interviewers once the latter gives them their contact details; the establishment of these channels is an ethical requirement.

van Manen M [1] states that the researcher should be personable in order to win the trust of the interviewee and it is often important to develop a relationship of personal sharing, closeness, or friendliness before seriously opening up the topic of research. An outside presence often triggers the realization that the couple needs to discuss more between themselves; an interview affords them the first opportunity to do so $[14,34]$.

\section{Safety of the children}

It was necessary to know how children would be taken care of during the interviews. Most of the participants had a babysitter. One twin pair was only five months old, so their parents took care of them. In some of the families, all the children were wasting videos or playing together or were asleep. All this was the result of participants organizing things in preparation for the interview. We paused whenever these children needed their parents. Brief interruptions by the children hardly affected the interview. Children's comfort is of prime importance; the interview should not entail a prolonged separation of the children from their parents. Careful planning enables participants to participate despite not having a babysitter (Table 2).

\section{Limitations}

Phenomenological hermeneutic studies respect natural enquiry into real contexts. Researcher tries to create the conditions where the data is real. It means also to reflect on her presents and own disturbance of the family. Researcher has to be very aware of the families' circumstances. The ideal situation is that all the children have babysitter and parents can concentrate fully on interviews. But researcher has to accept also the parents' choice that children will be present. This could also give relaxion and possibility to parents to involve this research. The children's safety is paramount. Despite the best planning attempts, something unexpected might crop up or go awry; the interviewer then requires the presence of mind to tackle such situations in order to undo the derailment.

\section{Discussion}

Conducting home interviews is a good opportunity for researchers to meet interviewees in a familiar environment. This means listening to participants' voices and giving them a platform to make themselves visible. Researchers have to bear in mind that children are all of a sudden denied a monopoly of parental attention. What the researchers can do, given the circumstances, is to keep this interruption to a minimum, with the least possible inconvenience to the family. Although data collection is the researcher's purpose, children's rights come first and foremost $[35,36]$. Ethical behaviour arises from the background of human rights and their protection - for example, the right to decide one's own affairs, privacy and dignity $[37,38,39]$. Researchers should give the utmost consideration to their participants who have agreed to the interview voluntarily by accommodating their wishes as far as possible [40].

Researchers are required to follow a set of guidelines on research ethics, including respecting participants. The needs of vulnerability participants' [41] should be taken in to account. In current research for example, breast-feeding mothers, who need greater protection; researchers should listen carefully, provide support, be empathetic and sensitive to non-verbal communication. DiCicco-Bloom B $\&$ Crabtree BF [42] consider four ethical issues of the qualitative research interview process: reducing unanticipated harm, protecting interviewer information, effectively informing interviewees about the study, and reducing exploitation risks. Although these aspects were important in the current study, researcher would like to stress researcher preparation and the safety aspects which are not limited to the participants [7]. The members of a research group, for example, should be aware of the researcher's whereabouts at the time of the interview.

In qualitative research, subjects could be sensitive [1,2]. The research process is meant to be transparent to the participants, as in the current research. They are informed at the outset what participation entails, the phases involved, and are aware that they can withdraw at any time. Understanding aspects of the participants' lives requires a high degree of sensitivity. Participants should be guaranteed privacy and anonymity. Only researchers know the link between data and participants.

Haahr A, et al. [8] state that the researcher is guided by bioethical principles, but these are not sufficient to prepare researchers for unanticipated ethical dilemmas related to qualitative research interviews. As a teacher of nursing, researcher find that using simulation pedagogy can be very useful in performing interviews and let ethical aspect to be present in learning process to openly discuss and share. This will deepen understanding and learning process.

This method enables concurrent learning of different aspects of human behaviour and interaction, honing observation skills and facilitating discussion on ethical issues. Students can holistically develop skills vital for nursing care.

Interviewers who are positively charged affect the interview dynamics. Interviewees tune into this energy and can reciprocate better, resulting in an optimal interview. The aim is not to just gather material; it is a question of respecting other people's lives. The importance of debriefing the total experience afterwards is realised by researchers in various of studies $[4,5]$. Aurini JD, et al. [3] state also that researchers will often have to work around the participants' schedule and location preferences, which may or may not be ideal from a convenience, safety, interview quality, or recording quality standpoint. 


\begin{tabular}{|c|c|c|}
\hline Home interviews & Meaning & Reflection \\
\hline $\begin{array}{l}\text { It takes quite a long time to have all the permissions needed. I got } \\
\text { the ethics approval from the Ethics Committee of the University } \\
\text { Hospital and health care organizations. Before that I have to send } \\
\text { more information on how to support and guide these families if I } \\
\text { notice need for help myself. } \\
\text { It was nice to see that the public health nurses gave me so much } \\
\text { help; they called the parents and asked for permission to give } \\
\text { their contact information to me. I interviewed parents after giving } \\
\text { them information on the research and receiving their oral and } \\
\text { written informed consent. I provided parents with all the requisite } \\
\text { information and told them about the possibility to withdraw } \\
\text { from the study any time. They may have found tape-recording } \\
\text { disturbing at first but I noticed that parents soon forgot about it. }\end{array}$ & $\begin{array}{l}\text { Respecting participants } \\
\text { and guidelines of } \\
\text { research ethics. } \\
\text { Having a strong desire } \\
\text { to do this research right } \\
\text { way. }\end{array}$ & $\begin{array}{l}\text { Researcher is required to follow a set of guidelines on research ethics. } \\
\text { Special attention needs to be paid to vulnerable groups. } \\
\text { Receiving a positive statement from a panel of ethical experts, the } \\
\text { researcher is reassured that the research pro-posed has an adequate } \\
\text { ethical level. } \\
\text { Participants were there of their own volition and were no coerced. } \\
\text { During the interview process the researcher is on full alert, ready to } \\
\text { observe factors and events going on around them and to report them } \\
\text { to the authorities concerned if the need arises. At times, advising the } \\
\text { parent might suffice. I must be fully involved in that situation in toto. }\end{array}$ \\
\hline $\begin{array}{l}\text { Outside of the family home is twin pram. I am sure that I have } \\
\text { found the right place. The right family name is on the door. The } \\
\text { parents come to open it, laugh, and welcome me. They say "try } \\
\text { to jump over all these things and come in". There are lots of little } \\
\text { shoes and different kinds of toys in the hallway. } \\
\text { At times, twins are on all fours. Some are already on their own } \\
\text { feet. Others are carried: one by each parent. Twins looked on } \\
\text { curiously at a stranger and new faces rouse their curiosity. } \\
\text { Children show me their cars and toys, I have the opportunity push } \\
\text { a pram and look into the twins' bedrooms and see them asleep. }\end{array}$ & $\begin{array}{l}\text { Jump into the life of a } \\
\text { multiple-birth family. } \\
\text { Lots of joy } \\
\text { Strange/ guest } \\
\text { Trust } \\
\text { Experience that I am } \\
\text { welcomed by the } \\
\text { family. }\end{array}$ & $\begin{array}{l}\text { An interview is a delving into and a dwelling on-albeit } \\
\text { temporality - the unique universe of the host family, respecting the } \\
\text { time given to me and their life situation just as it is. } \\
\text { Although the researcher is invited to and into the home, s/he has to } \\
\text { bear in mind that his/her entry is in effect an intrusion, an invasion of } \\
\text { private space, and in a different situation and period. } \\
\\
\text { Although data collection is the researcher's purpose for being there, } \\
\text { children's rights should come first and foremost. } \\
\text { Although the research focuses on multiple-birth parents, some of their } \\
\text { children are also involved in the interviewing process. Their needs } \\
\text { have to be catered for. }\end{array}$ \\
\hline $\begin{array}{l}\text { Some families have a babysitter taking care of the children or } \\
\text { they are already asleep in the evening. Twins are playing in a } \\
\text { room, and parents can see them all the time. We took breaks } \\
\text { when necessary. Once, we paused when needed. One little twin } \\
\text { boy comes and drives a tractor on my arm. At times, there is a } \\
\text { children's program on. We can observe them watching. }\end{array}$ & $\begin{array}{l}\text { Organizing the } \\
\text { interview time. }\end{array}$ & $\begin{array}{l}\text { The researcher has to minimise the disturbance. Parents have done } \\
\text { different kinds of things to organise the time for interview. The } \\
\text { researcher gave the parents the possibility of choosing the time which } \\
\text { is best for them. } \\
\text { Home interview dynamics require that both parents be mutuality } \\
\text { accommodating. }\end{array}$ \\
\hline $\begin{array}{l}\text { Most of the multiple-birth families have a babysitter. The needs } \\
\text { of the children are the most important thing. We had pauses when } \\
\text { children needed their parents. While one parent went to help } \\
\text { them, another parent continued telling his/her story and the other } \\
\text { heard the story. Later if needed, I repeated what she/he said. I } \\
\text { underlined the importance of the safety of the children during the } \\
\text { interview. }\end{array}$ & $\begin{array}{l}\text { Safety of the children. } \\
\text { Working with different } \\
\text { situations. } \\
\text { Children needs come } \\
\text { first. }\end{array}$ & $\begin{array}{l}\text { What then researcher can do, given the circumstances, is to keep this } \\
\text { interruption to a minimum, with the least possible inconvenience to } \\
\text { the family. The researcher can also recommend the parents try to find } \\
\text { a babysitter during interview. Interviewing requires sensitivity to the } \\
\text { participants, including the silent ones - the children around. Should a } \\
\text { factor demanding attention arise (especially one related to child safety } \\
\text { and rights), the process has to be paused. Despite the temporary loss } \\
\text { of concentration, the researcher is expected to re-focus on the topic as } \\
\text { soon as the situation permits; flexibility is key. Situational awareness } \\
\text { needs to be accompanied by the ability to think on one's feet. }\end{array}$ \\
\hline $\begin{array}{l}\text { Many parents told me that it was nice to sit down and talk and } \\
\text { share their experiences. In their busy daily life, they do not have } \\
\text { possibility for it. Some parents reported that they like to continue } \\
\text { the discussion between themselves later and suggested they try to } \\
\text { find time. They really liked to listen to the other parent. }\end{array}$ & $\begin{array}{l}\text { Relationship between } \\
\text { parents and researcher. } \\
\text { The interview should be } \\
\text { holy present. } \\
\text { Time for relationships. }\end{array}$ & $\begin{array}{l}\text { Researcher needs to strike a balance between obtaining adequate } \\
\text { data and interrupting the normal flow of family life. Being wholly } \\
\text { present is an acknowledgement of the family's goodwill in inviting } \\
\text { the researcher into their home. An interview allows the couple to } \\
\text { discuss more between themselves. Interviewees can be in touch } \\
\text { with interviewers once the latter gives them their contact details; the } \\
\text { establishment of this channel is an ethical requirement. }\end{array}$ \\
\hline
\end{tabular}

Table 2: Extracts from researchers research diary and reflection.

There seem to be various reasons for parents to participate in the research. Those who themselves received inadequate support are altruistic in their wish to be of use to future generations. They understand the importance of talking about their experiences. Ethics require researchers to appreciate participation despite potential feelings of tiredness and intrusion of privacy. Even review committees sometimes express concern that the process may be stressful for some of the participants [34].

Participants took time off from their busy schedules to participate. Researcher did not want to add to their work, but they went out of their way to make researcher feel at home. The interviews led to fruitful discussion regarding their life's in an atmosphere of openness and trust [23]. When researcher interviewed participants together, both were given an equal opportunity to interact and explain how they raised their children and reflect on and share their decisions. This process could also act as a boost to their selfconfidence as parents. Researcher noticed that mothers tended to dominate during the discussions. Reid J, et al. [34] point out the importance of ensuring that the less dominant participants have an opportunity to share their viewpoints. The interviews afforded time together, stirring up memories, and sharing their lived experiences. Discussions, however animated, never degenerated into arguments. On the other hand, interviewing parents separately 
has its own advantages. A parent might be unwilling to discuss an issue or reveal some information in the presence of the other. However, this entails careful planning to avoid the intrusion of other family members during such a session.

Kendall M, et al. [43] noticed that participants can help each other during interview and that interview could lead to discussion [8], but the data may also be influenced by the presence of both participants leading to an account of shared rather than individual experience [44]. In the current research, roughly half of the interviews were of couples; the remainder were of mothers, with no bias between the two groups. Although all experience is individual, the amount of shared experiences was substantial. Individual interviews sometimes shifted to the perspective of the absent spouse; the researcher's duty to listen patiently and eventually steer the conversation back to the actual experience.

To fulfil social and health care professionals' responsibility to multiple-birth families, personnel first need to be equipped with relevant knowledge, practical skills and special education. Researchers would do well to keep in mind these aspects of health care practice ethics. These aspects both facilitate their understanding of participants and their situations and warrant further research.

\section{Conclusion}

The current article examines various aspects of the interviewing process, outlines the many steps involved, and discusses the ethical and practical aspects. Home interviews are specific situations that require effective communication between the researcher and participants. The researcher need to prepare for the situation carefully, concentrate, and harness all his/her senses.

Students need more training in interviewing, preparation for unexpected situations and the opportunity to reflect on their experiences with their supervisors afterwards. Using simulation pedagogy and also discussion within a group of researchers could lead to mutual learning. In further studies it would be interesting to do interviews together with participants and professionals and develop an evidence-based research practice.

\section{Acknowledgments}

The author wishes to thank the parents of twins for sharing their experiences for participation in this research. I also thank Gerald Netto for helping with the language revision of the manuscript.

The author disclosed receipt of the following financial support for the research: Ministry of Social Affairs and Health.

\section{References}

1. van Manen M. Phenomenology of Practice: Meaning-Giving Methods in Phenomenological Research and Writing. Walnut Creek, CA: Left Coast Press. 2014.

2. Kylmä J, Juvakka T. Laadullinen terveystutkimus. Edita Prisma Oy. Helsinki. Finland. 2007.

3. Aurini JD, Heath M, Howells S. The how to of qualitative research. Sage Publication Ltd. California. 2016.

4. MacDonald K, Greggans A. Dealing with chaos abd complexity: the reality of interviewing children and families in their own homes. Journal of Clinical Nursing. 2008; 17: 3123-3130.

5. Reid J, Schmied V, Sheehan A, et al. "Be our guest": challenges and benefits of using "family conversations" to collect qualitative data about infant feeding and parenting. Journal of Clinical Nursing. 2013; 23: 2404-2413.

6. Sorsa M, Kiikkala I, Åstedt-Kurki P. Bracketing as a skill in conducting unstructured qualitative interviews. Nurse Researcher. 2015; 22: 8-12.

7. Donalek JG. The interview in qualitative research. Demystifying Nursing research. Urologic Nursing. 2005; 25: 124-125.

8. Haahr A, Norlyk A, Hall E. Ethical challenges embedded in qualitative research interviews with close relatives. Nursing Ethics. 2014; 21: 6-15.

9. Gormley GJ, Fenwick T. Learning to manage complexity through simulation: students' challenges and possible strategies. Perspectives on Medical Education. 2016; 5: 138146.

10. Anderson A, Anderson B. Toward a substantive theory of mothering attachment. The American Journal of Maternal/ Child Nursing. 1990; 15: 372-377.

11. Beck CT. Releasing the pause button. Mothering twins during the first year of life. Qualitative Health Research. 2002; 12: 593-608.

12. Goshen-Gottstein ER. The mothering of twins, triplets, and quadruplets. 1980. Psychiatry; 43: 189-204.

13. Bolch CE, Umstad MP, Fisher JRW. Multiple birth families with children with special needs: a qualitative investigation of mother's experiences. Twin Research and Human Genetics. 2012; 15: 503-515.

14. Damato EG, Burant C. Sleep patterns and fatigue in parents of twins. Journal of Obstet Gynecol Neonatal Nursing. 2008; 37: 738-749.

15. Heinonen K, Moilanen I, Pietilä A-M. Experiences of support by parents of multiple birth children an interview study. Nursing Science. 2007; 19: 223-235.

16. Jenkins D, Coker R. Coping with Triplets: Perspectives of Parents during the First Four Years. Health \& Social Work. 2010; 35: 169-180.

17. Josse D, Robin M. Some aspects of mother-child relationships following the birth of twins. Early Child Development and Care. 1986; 26: 1-18.

18. Van der Zalm JE. Accommodating a twin pregnancy: maternal processes. Acta Genet Med Gemellol. 1995; 44: 117-133.

19. Holditch-Davis D, Roberts D, Sandelowski M. Early parental interactions with and perceptions of multiple birth infants. Journal of Advanced Nursing. 1999; 30: 200-210.

20. Ball HL. Together or apart? A behavioral and physiological investigation of sleeping arrangements for twin babies. Midwifery. 2007; 23: 404-412.

21. Harvey ME, Athi R, Denny E. Exploratory study on meeting the health and social care needs of mothers with twins. 
Community Practitioner. 2014; 87: 28-31.

22. Heinonen K. Dimensions and possibilities in multiple birth parenthood (Master's thesis). University of Kuopio. Abstract in English. Finland. 2004.

23. Heinonen K. The lifeworld of multiple-birth families from being on guard to strengthening parenthood. A phenomenological-hermeneutic study (Dissertation in Health Sciences). The University of Eastern Finland. 2013.

24. ICOMBO. Declaration of the Rights and Statement of needs of Twins and Higher Order Multiples. International Council of Multiple Birth Organisations. 2017.

25. http://www.suomenmonikkoperheet.fi/

26. McKenzie P. The seeking of baby-feeding information by Canadian women pregnant with twins. Midwifery. 2006; 22: 218-227.

27. van Manen M. Pedagogical Tact. Knowing what to do when you don't know what to do. Walnut Creek, CA: Left Coast Press. 2015.

28. van Manen M, Higgins I, van der Rieth P. A conversation with Max van Manen on phenomenology in its original sense. Nursing and Health Science. 2016; 18: 4-7.

29. Heinonen K. Levels of reduction in van Manen's phenomenological hermeneutic method: an empirical example. Nurse Researcher. 2015a; 22: 20-24.

30. Heinonen K. Methodological and hermeneutic reduction a study of Finnish multiple-birth families. Nurse Researcher. 2015b; 22: 28-34.

31. Heinonen K. Understanding the lives of multiple-birth families: Listening to the voices of parents and professionals. Nursing and Palliative care. 2017; 2: 1-11.
32. The Finnish Advisory Board on Research Integrity. 2012.

33. Hirsjärvi S, Hurme H. Tutkimushaastattelu. Teemahaastattelun teoria ja käytäntö. Raamaturukikoda. Tallinna. 2011.

34. Morse JM, Field PA. Nursing research. Padstow, Cornwall: TJ International. 1998.

35. UNCRC. The United Nations Convention on the Rights of the Child. Convention of the rights of the Child. 1989.

36. http://www.un.org/en/universal-declaration-human-rights

37. ANA American Nurses Association Code of Ethics for Nurses with Interpretive Statements.2015.

38. Harber J. Legal and Ethical Issues. In G. LoBionde-Wood, \& J. Haber (Eds.), Nursing Research. Methods and Critical Appraisal for Evidence-Based Practice (6th edn). Mosby: Elsevier. 2006.

39. The Finnish Nurses Association. Ethical Guidelines for Nursing. 2015.

40. Declaration of Helsinki World Medical Association Declaration of Helsinki. Ethical Principles for Medical Research Involving Human Subjects. 1964.

41. Finnish law. Laki lääketieteellisestä tutkimuksesta 488/1999.

42. DiCicco-Bloom B, Crabtree BF. The qualitative research interview. Medical education. 2006; 4: 314-321.

43. Kendall M, Carduff E, Worth A, et al. Use of multi perspective qualitative interviews to understand patients' and carers' beliefs, experience and need. British Medical Journal. 2009; 340: 196-209.

44. Norlyk A, Haahr A, Hall E. Interviewing with or without the partners present? An underexposed dilemma between ethics and methodology in nursing research? Journal of Advanced Nursing. 2015; 72: 936-945. 